\title{
Konfrontas J Joumal: \\ About Some Actual Problems of the Methodology of Research of State Legal Phenomena
}

\author{
Vladimir Valentinovich Kozhevnikov \\ Department of Theory and History of State and Law, Omsk State University Dostoevsky, Omsk, Russia \\ kta6973@rambler.ru
}

\begin{abstract}
This scientific article is devoted to the consideration of some methodological problems of the study of state and legal phenomena. The main purpose of the work is to draw the attention of the scientific community to those general theoretical methodological issues that are ambiguously solved by scientists and which are important for legal science. To achieve this goal during the study, the following tasks were solved: 1) substantiate the importance and necessity of the general philosophical method; 2) to argue the unacceptability of the religious and moral approach to the study of state and legal reality; 3) dialectically assess such a methodological principle as the principle of scientific pluralism. In conclusion, it is concluded that, firstly, that general philosophical methods, in particular and especially the method of dialectical and historical materialism, which form the methodological basis for the scientific study of state-legal phenomena, should not be ignored, because they reveal the most general laws of the movement of human thought to the truth, concentrating all the most important and essential that is contained in other methods; secondly, the religious philosophy of believers should not be included in the potential of the methodology of cognition of state and legal reality; thirdly, the methodological principle of scientific pluralism must have appropriate boundaries.
\end{abstract}

Keywords

methodology, general philosphical method, principle of scientific pluralism historical and dialectical materialism

\section{Introduction}

The relevance of the problems of the methodology of studying state-legal phenomena considered in the article does not raise any doubts, because the final result of activity in any area (scientific, practical, etc.) depends not only on who acts (the subject) or what is aimed at, but and on how this process is carried out, what methods, techniques and means are used in this case. The importance of methodological foundations in the knowledge of the state, law, state-legal phenomena is due to the fact that methodology is a condition without which it is impossible to understand the complex and contradictory essence of state-legal processes and phenomena. In this regard, Alexei Vasilievich Surilov noted the following: "In legal knowledge, methodology is necessary, since it ensures the improvement, and therefore, the fruitfulness of the methods of this knowledge ... Nothing can be improved without its cognitive development, the quality of which is determined primarily by on what methodological basis it is being improved "[1]. We should agree with the statement of Nikolai Nikolaevich Tarasov, who asserts that "methodological research for our jurisprudence today is perhaps more practically significant than any meaningful specific research, because the reliability of the latter, the correctness and applicability of their results directly depend on the degree of development of the methodology of legal science" [2]. 
Konfrontasi Journal: Culture, Economy and Social Changes, 7 (4) December 2020, 275-281

ISSN: 1410-881X (Print), 2716-2095 (Online)

Vladimir Valentinovich Kozhevnikov: About Some Actual Problems of the Methodology of Research of State Legal Phenomena

DOI: https://doi.org/10.33258/konfrontasi2.v7i4.125

http://www.konfrontasi.net/index.php/konfrontasi2

\section{Research Methods}

When preparing a scientific article, the following methods were used:

General philosophical (dialectical-materialistic), which is used in all social sciences;

a. General scientific (analysis and synthesis, logical and historical, comparisons, abstractions, etc.), which are used not only by the theory of state and law, but also by other social sciences;

b. Special methods (philological, cybernetic, psychological, etc.), developed by special sciences and widely used for the knowledge of state and legal phenomena;

c. Private scientific (formal legal, interpretation of law, etc.), which are developed by the theory of state and law.

\section{General Philosophical Methods of Cognition of State Legal Phenomena}

An analysis of modern domestic legal literature shows that theoretical scientists do not pay due attention to general philosophical methods of cognition of state-legal phenomena, limiting themselves to a few sentences when characterizing them or ignoring them altogether. So, Valery Vasilievich Lazarev and Sergey Vasilievich Lipen argue that only general scientific and specific scientific methods of studying state-legal phenomena should be distinguished. True, although unreasonably, the authors believe that a certain philosophical trend (materialistic dialectics, neo-Kantianism, neo-Hegelianism, a certain religious ideology, positivism, existentialism, utilitarianism, etc.) acts as general scientific methods, or the methodological basis of research [3] ... At one time, Nikolai Andreevich Pyanov believed that "the modern domestic theory of state and law uses a variety of methods that can be subdivided into general, special and particular" [4]. For the sake of fairness, we note that earlier the scientist, as part of the method of the theory of state and law, singled out philosophical and worldview approaches as one of their elements, which constitute the methodological basis of the theory of state and law. At the same time, it was emphasized that "in contrast to the Soviet theory of state and law. which was based only on Marxist-Leninist philosophy, the modern Russian theory of state and law is not bound by ideological fetters and, in fact, can (emphasized by us - Vladimir Valentinovich Kozhevnikov) use any philosophical and worldview approaches "[4]. This position is close to the point of view of Nikolai Nikolaevich Tarasov, who emphasizes that "the overwhelming majority of the fundamental theoretical concepts of Soviet jurisprudence were formed in accordance with the fundamental provisions of Marxist doctrine and developed within its framework" [2].

\section{a. The Importance of General Philosophical Methods}

It seems that the significance of general philosophical methods is very great. Speaking about philosophical methods (methodological approaches), the literature drew attention to the fact that such philosophical postulates exist in absolutely any scientific discipline, being present in the course of scientific research quite tangibly as common initial attitudes and universal fundamental principles, in general, forming the methodological basis of scientific research [5]. Scientists notice that philosophical methods set only the most general regulations for research, its general strategy, but do not replace special methods and do not determine the final result of cognition directly and directly [6]. Experience shows that "the more general the method of scientific knowledge, the more uncertain it is in relation to the prescription of specific steps of cognition, the greater its ambiguity in determining the final results of research" [7]. But this does not mean that philosophical methods are not needed at 
all, because, as the history of cognition testifies, "an error on the highest levels of cognition can lead an entire research program to a dead end" [7].

\section{b. The Method of Dialectical and Historical Materialism as a General Philosophical Method}

A very paradoxical situation has developed in domestic jurisprudence: despite the criticism of Marxism-Leninism by modern legal scholars, the method of dialectical and historical materialism, which has made a huge contribution to the knowledge of political and legal reality, is recognized as a general philosophical method. Vyacheslav Nikolayevich Zhukov, referring to this method, writes that at present, to consider the state and law in development, historically, in the unity of the political, spiritual and economic life of society, based on social practice as a criterion of truth has become characteristic of the methodology of theoretical and legal science [eight]. At the same time, scientists noticed that, while recognizing pluralism in philosophical and legal concepts, one should always test them for strength, critically assess their heuristic capabilities. Attempts by lawyers to artificially, rather arbitrarily combine philosophy and jurisprudence often lead to the construction of speculative schemes (for example, concepts based on phenomenology and existentialism) [8].

As for our attitude to the possibilities of using the potential of another method hermeneutics in jurisprudence, it is, like a number of scientists, quite critical $[9,10]$. For example, Vladimir Mikhailovich Syrykh, in our opinion, convincingly showed the futility of hermeneutics as a method of cognition in law [11]. Apparently, and most likely, this circumstance is due to the fact that this method is very rarely included in the system of methods of cognition of law.

It should be noted that even those scholars who pinned certain hopes on legal hermeneutics in terms of research are now beginning to doubt its potential. For example, Ilya Lvovich Chestnov, having named his monograph "Legal Understanding in the Postmodern Era", having analyzed phenomonology, hermeneutics, synergetics, etc. in it, came to the conclusion that these approaches to law as independent have not yet taken place "[12]. In this regard, Igor Yurievich Kozlikhin quite reasonably notes that the last decade has been characterized by the search for a new paradigm. More and more often they are trying to find it outside the law, to involve in the study of law the knowledge developed in the bosom of other sciences. This is most clearly manifested in the general theory. The scientist believes that such attempts should be welcomed, but only if they deepen our knowledge about law, and not about the subject of those sciences to which we turn [13].

It seems that the method of dialectical and historical materialism has not lost its relevance in modern legal research. At present, to consider the state and law in development, historically, in the unity of the political, spiritual and economic life of society based on public practice as a criterion of truth has become characteristic of the methodology of theoretical legal science.

Dialectical and historical materialism is a philosophical directional created by Friedrich Engels based on the logic of Georg Wilhelm Friedrich Hegel and the materialism of Ludwig Feuerbach. Dialectical materialism as a theory and method of cognition includes a number of fundamental principles: 1) the principle of the unity and materiality of the world, according to which matter is primary in relation to consciousness; 2) the principle of the cognizability of the world, proceeding from the fact that the world around us is cognizable and that the measure of its cognition, determining the degree of correspondence of our knowledge to objective reality, is social production practice; 3) the principle of development, asserting that all phenomena in the world and the world as a whole are in continuous, constant dialectical development, the source of which is the emergence and resolution of internal contradictions 
leading to the denial of certain states and the formation of fundamentally new phenomena and processes; 4) the principle of active transformation of the world, based on which people should not only learn about the world, but also purposefully change it.

A number of Russian scientists advocate dialectical-materialist dialectics. For example, Vladimir Konstantinovich Babaev warned former ardent adherents of Marxist philosophy against yet another extreme and derogatory criticism addressed to it, wrote that foreign sociologists, economists, philosophers, lawyers, Sovietologists, who never accepted Marxism and criticized it, nevertheless treat it with due respect. to him as a teaching, take into account in their studies. This is what we should do, because to reject it completely is as foolish as to blindly dogmatically confess [14]. Domestic scientists, in our opinion, quite reasonably declare that today there are no convincing arguments against the use of materialistic dialectics as one of the variants of the theoretical outlook and elements of the methodology of scientific research. In the modern "philosophical market, it is quite competitive" [15]. American professor Lauren Graham believes that "... the dialectical-materialist approach scientifically oriented, realistic, materialistic - claims to be superior to existing and competing universal systems of thought, and these claims can be quite justified" [16].

\section{Discussion}

\subsection{On the Religious Philosophy of the Faith: Supporters and Opponents}

Let's pay attention to the following, in our opinion, the fundamental statement of some authors: "We proceed from the methodological tradition of Russian jurisprudence, according to which science and religion do not contradict each other. True realists should be considered precisely those scientists who adequately perceive the world, which has both material and spiritual dimensions, and is cognized in two complementary ways. Outstanding scientists who made a major contribution to world science at one time did not hide the fact that they were believers "[17]. It seems that the use of a religious philosophy of faith, a striking example of which is Christian philosophy, presupposes that the state and law are studied through the prism of biblical dogmas. Recognizing that in the writings of religious philosophers there is a lot of value about the nature and functioning of state and law, it is necessary to emphasize that all this rational knowledge is subordinated to one ultimate goal: to prove the dependence of political and legal reality on the will of God, its inclusion in the general divine world order [18] ... The use of the religious and moral approach by the authors necessitated that many problems of legal responsibility are interpreted taking into account religious dogmas [19]. For example, they assert that "the religious philosophy of law is not inferior to secular science in three main criteria: first, in the most complete and comprehensive study of law; secondly, in the analysis and synthesis of the facts obtained on the basis of a certain methodology; thirdly, in the presence of an integral system of worldview, which makes it possible to explain the meaning of the studied legal phenomena both in historical and essential aspects "[17].

It seems important to pay attention to some objections directed against the religious and moral approach, the Orthodox theory as a whole, expressed by Orest Vladimirovich Martyshin. Their essence boils down to the following provisions: 1) what has received the name "Orthodox theory of law" does not correspond to the position of the ROC, which found expression in its Fundamentals of Social Platform, adopted in 2000 and fully consistent with the principles of the current constitution, in which a clear line is drawn between spiritual and secular power, church and state law; 2) without exaggerating the originality of this theory, it is noted that its novelty lies only in the fact that for almost a century it has not figured in 
literature and social and political life as a national development program; 3) along with the socio-political basis and significance, the Orthodox theory also acquires a potential danger, since it is aimed at denying the basic values proclaimed by the current Constitution of the Russian Federation [20].

\subsection{Methodological Principle of Scientific Pluralism}

Note that many legal scholars, in addition to the techniques and methods of scientific activity used to obtain true, reflecting the objective reality of knowledge, in the methodology include the principles of knowledge [3]. Vladimir Ivanovich Chervonyuk argues that in a narrow sense, the methodology of jurisprudence is the doctrine of the principles, methods, methods of scientific knowledge of the subject of the theory of state and law. In this sense, the methodology of this legal science is a theoretical explanation of the foundations and principles of objective knowledge of state and legal reality, as well as logical methods and techniques for their study [21]. We believe that among the system of methodological principles, the principle of scientific pluralism (lat. Pluralis- plural) has a special place [22], implying scientific tolerance (tolerance), the ability to use all that valuable that has been accumulated by the legal science of different countries and eras to create a whole system of ideas about the state and law. The pluralistic approach is opposed by the monistic approach, which for a long time dominated in Soviet legal science, in which only one was considered correct - the Marxist-Leninist class theory of state and law; other theories were recognized as false and criticized, including the theory of the rule of law [23]. The Afghan scientist Hashmatullah Behruz, in relation to the methodology of comparative legal research, formulates one of the requirements as follows: "rejection of the methodological monism based on Eurocentrism, which prevailed for a long time in theoretical and historical research (including state-legal phenomena), which implies the use of the principle of pluralism in choosing methodological approaches and techniques "[24].

\section{Dialectical Assessment of the Principle of Scientific Pluralism}

Undoubtedly, the principle of scientific pluralism in jurisprudence allows one to see the palette of scientists' views on one and the same theoretical problem, predetermines the possibility of scientific discourse in finding objective truth. Although, in fairness, we note that a number of authors evaluate this principle in a different way, more restrained and even to some extent and negatively. Thus, the variety of interpretations of the essence and nature of law in Russian legal science is often viewed as a very positive phenomenon, indicating a fairly high level of development of legal science, and above all the theory of law. They say, thanks to different interpretations of the essence of law and its social nature, different sides, facets of law are revealed, which contribute to its in-depth and comprehensive knowledge. However, according to Vladimir Mikhailovich Syrykh, the situation with many interpretations of the essence and social nature of law deserves negative rather than positive assessments, because the fact that scientists cannot yet solve this problem, which leaves the core, the basis of the theory of law, indicates an insufficiently high level of this science has so far been forced to be content with a number of original, but very contradictory and insufficiently reasoned hypotheses [25]. In this regard, the reasoning of Pyotr Pavlovich Serkov is of interest, who drew attention to the fact that "... it remains unclear how to use discrepancies in legal research, for example, when organizing the activities of local government bodies or when resolving conflicts that have arisen by judicial authorities" [26]. Noting that the right of a researcher to his point of view is, in principle, undeniable due to the constitutional freedom of belief (Article 28 of the Constitution of the Russian Federation). 
However, according to the scientist, “... the existing dispersion of scientific points of view on the same issue actually means not pluralism of opinions, but non-identification of regularities. Therefore, one cannot reduce to the freedom of scientific views the explanations why, on the basis of the same initial data on the same problem, there is a variety of scientific proposals "[26]. Bearing in mind the data, well-reasoned remarks, it should be emphasized in a categorical form that the inclusion of the principle of scientific pluralism in the arsenal of modern methodology of jurisprudence does not exclude, but on the contrary, presupposes the establishment of appropriate boundaries, beyond which the researcher is prohibited. Otherwise, the probability of unscientific, illogical theories that have neither theoretical nor practical meaning is very high. It seems that one of the examples of this pseudo-scientific creativity is, sharply criticized by us and many theoretical scientists, [27] the theory of positive legal responsibility, according to which legal responsibility is understood as the subject's awareness of the right of his duty (special duties) to society, the collective, social groups ... The subject assigns such responsibility to himself, as it were, for the future results of his lawful behavior. We are talking about additional, active (in comparison with other subjects of law) efforts, loads in certain areas of people's life, which lead to certain positive results. For the success of the mission undertaken and the final results, the individual assumes the indicated responsibility [28]. And here we are quite in solidarity with Vitaly Viktorovich Sorokin, who believes that it is time to close the problem of so-called positive legal responsibility as theoretically and practically untenable; there is no positive legal responsibility [29]. It seems that sane scientists in their research should be guided by the position that was substantiated by Vyacheslav Nikolayevich Zhukov: "If ... the conceptual apparatus developed by legal science is not suitable for legal regulation, no one needs such a science. If the country's lawyers (scientists and practitioners) are not capable of either developing a dogma or preparing a normative act ... then an unambiguous conclusion should be made that there is no legal science or that it is profane "[8].

\section{Conclusion}

In conclusion, we emphasize that, firstly, general philosophical methods, in particular and especially the method of dialectical and historical materialism, which form the methodological basis for the scientific study of state and legal phenomena, should not be ignored, because they reveal the most general laws of the movement of human thought to truth, concentrating everything the most important and essential that is contained in other methods; secondly, the religious philosophy of believers should not be included in the potential of the methodology of cognition of state and legal reality; third, the methodological principle of scientific pluralism must have appropriate boundaries. 


\section{References}

[1]. Surilov Alexey Vasilievich. Theory of state and law: textbook. Kiev; Odessa: Vishcha school, 1989. Pp. 49-50.

[2]. Tarasov Nikolay Nikolaevich. Methodological problems of legal science. Yekaterinburg: Publishing house of the Humanitarian University, 2001.Pp. 3, 29.

[3]. Lazarev Valery Vasilievich, Lipen Sergey Vasilievich. Theory of State and Law: Textbook), Moscow: Yurayt. Pp.22, 132.

[4]. Pyanov Nikolai Andreevich. Consulting on the theory of state and law: textbook. Irkutsk, Publishing house of the Irkutsk state. University, 2010. Pp. 19-20.

[5]. Kozhevnikov Vladimir Valentinovich, Senin Igor Nikolaevich. Methodology of the theory of state and law: textbook) Omsk: Omsk Economic Institute. P.49.

[6]. Kokhanovsky Valery Pavlovich, Leshkevich Tatiana Gennadievna, Matyash Tamara Petrovna, Fatkhi Tatiana Borisovna. Fundamentals of the philosophy of science: textbook. Rostov n / a: Phoenix, 2010.P. 318.

[7]. Kravets Alexander Samuilovich. Methodology of Science. Voronezh: Voronezh University, 1991.Pp. 13, 15.

[8]. Zhukov Vyacheslav Nikolaevich. Philosophy of law: textbook. Moscow: World of Philosophy, Algorithm, 2019.Pp.37, 39.

[9]. Vlasenko Nikolai Alexandrovich. Methodological problems of modern theory of law // Journal of Russian law. 2019.P.8.

[10]. Kozhevnikov Vladimir Valentinovich. On the hermeneutic method in jurisprudence. // Bulletin of Omsk State University named after F.M. Dostoevsky. Right. 2020.T.17.No. 1. Pp.15-26.

[11]. Syrykh Vladimir Mikhailovich. The hermeneutic circle as a methodological dead end // Modern research methods in jurisprudence / ed. Nikolai Ignatievich Matuzov, Alexander Vasilyevich Malko. Saratov: Publishing house of the Saratov Law Institute of the Ministry of Internal Affairs of Russia 2007.Pp. 183-235.

[12]. Chestnov Ilya Lvovich. Legal Understanding in the Postmodern Era: Monograph: Publishing House of the St. Petersburg Institute for Foreign Economic Relations, Economics and Law, 2006.P. 272.

[13]. Kozlikhin Igor Yurievich. On non-traditional approaches to law // Jurisprudence. 2006. No. 1.P. 31.

[14]. General theory of law: a course of lectures / ed. Vladimir Konstantinovich Babaev. N. Novgorod: Nizhny Novgorod High School of the Ministry of Internal Affairs of Russia, 1993. P.6.

[15]. Baranov Vladimir Mikhailovich, Pershin Vladimir Borisovich, Baranova Marina Vladimirovna. The place and role of the method of materialistic dialectics in legal research // Philosophy of law. 2007. No. 3. P.10.

[16]. Graham Lauren. Natural science, philosophy and the science of human behavior in the Soviet Union. M .: Politizdat, 1991. P.15.

[17]. History and methodology of legal science: textbook / ed. Vitaly Viktorovich Sorokin. Barnaul: New format, 2016.Pp. 12-13, 14.

[18]. Theory of state and law: textbook / ed. Orest Vladimirovich Martyshin. M .: Norma, 2007.Pp. 31-39.

[19]. Kozhevnikov Vladimir Valentinovich. On the problems of the general theory of law (based on the analysis of the textbook for universities "History and methodology of 
legal science" / under the editorship of Vitaly Viktorovich Sorokin. // Agrarian and Land Law. 2018. No. 5. Pp.133-147.

[20]. Martyshin Orest Vladimirovich. Philosophy of law: textbook. M .: Prospect, 2017. P. 311.

[21]. Goyman-Kalinsky Igor Vladimirovich, Ivanets Galina Ivanovna, Chervonyuk Vladimir Ivanovich. Elementary principles of the general theory of law: textbook / ed. V. I. Chervonyuk. M.: KolosS, 2003.P. 24.

[22]. Philosophical Dictionary / ed. Mark Moiseevich Rosenthal. Moscow: Political Literature Publishing House, 1975.P. 317.

[23]. Kozhevnikov Vladimir Valentinovich. Theory of state and law as a science // Kozhevnikov Vladimir Valentinovich, Kozhenevsky Victor Boleslavovich, Rybakov Vladimir Alekseevich. Theory of state and law: textbook / otv. ed. Kozhevnikov Vladimir Valentinovich. M .: Prospect, 2020. P.11.

[24]. Behruz Khashmatullah. Comparative jurisprudence: textbook), Moscow: TransLit, 2008. P. 53.

[25]. Syrykh Vladimir Mikhailovich. Theory of state and law: textbook. M .: Justicinform, 2001.P. 492.

[26]. Serkov Petr Pavlovich. Legal relationship (Theory and practice of modern legal regulation): a monograph in 3 parts. Moscow: Norma, 2018.Part 1.Pp. 27, 29.

[27]. Kozhevnikov Vladimir Valentinovich, Karavaev Alexander Fedorovich, Zverev Vadim Olegovich. The status of positive legal responsibility in the conceptual and categorical apparatus of the general theory of law // Psychopedagogy in law enforcement agencies. 2018. No. 3. Pp.88-94.

[28]. Lyubashits Valentin Yakovlevich, Smolensky Mikhail Borisovich, Shepelev Vladimir Ivanovich. Theory of state and law: textbook. Rostov n / a: Phoenix, 2006. P. 462.

[29]. Sorokin Vitaly Viktorovich. The theory of legal responsibility: textbook. Barnaul: Altai State Publishing House. University, 2017.Pp. 45-46. 